\title{
Homeodomain-Interacting Protein Kinase 2
}

National Cancer Institute

\section{Source}

National Cancer Institute. Homeodomain-Interacting Protein Kinase 2. NCI Thesaurus. Code C102958.

Homeodomain-interacting protein kinase 2 (1198 aa, 131 kDa) is encoded by the human HIPK2 gene. This protein plays a role in protein phosphorylation, transcriptional regulation and cell cycle progression. 